\title{
Effects of hormonal priming on seed germination of pigeon pea under cadmium stress
}

\author{
LARISSA C. SNEIDERIS ${ }^{1}$, MARINA A. GAVASSI ${ }^{1}$, MARCELO L. CAMPOS ${ }^{2}$, \\ VICTOR D'AMICO-DAMIÃO ${ }^{1}$ and ROGÉRIO F. CARVALHO ${ }^{1}$ \\ ${ }^{1}$ Departamento de Biologia Aplicada à Agropecuária, Universidade Estadual Paulista "Júlio de Mesquita Filho", \\ Via de Acesso Prof. Paulo D. Castellane, s/n, 14884-900 Jaboticabal, SP, Brasil \\ ${ }^{2}$ Department of Energy-Plant Research Laboratory, Michigan State University, East Lansing, Michigan, 48824, USA \\ Manuscript received on June 30, 2014; accepted for publication on December 5, 2014
}

\begin{abstract}
In this work we investigated whether priming with auxin, cytokinin, gibberellin, abscisic acid and ethylene, alters the physiological responses of seeds of pigeon pea germinated under water and cadmium stress. Seeds treated with water or non-treated seeds were used as control. Although compared to non-treated seeds we found that the hormone treatments improve the germination of pigeon pea under cadmium stress, however, these treatments did not differ from water. However, we also observed a trend of tolerance to the effects of cadmium in the presence of ethylene, suggesting that the use of this hormone may be an efficient method to overcome seed germination under metal stress.
\end{abstract}

Key words: Cajanus Cajan, heavy metal, hormones, pretreatment in seeds, abiotic stress.

\section{INTRODUCTION}

Cadmium $(\mathrm{Cd})$ is a toxic heavy metal that has become a major pollutant due to improper agricultural and industrial activities. Low concentrations of Cd absorption can disrupt vital plant processes such as photosynthesis and nitrogen metabolism, thus adversely affect growth and productivity (Arasimowicz-Jelonek et al. 2011, Gill and Tuteja 2011, Cui et al. 2013). Additionally, Cd accumulation in crop plants poses a severe threat to human health (Jarup and Akesson 2009).

Seed priming is a technique that can be applied to improve germination and growth in heavy metal-contaminated areas. During priming, the

Correspondence to: Rogério F. Carvalho

E-mail:rfcarval@fcav.unesp.br germination process is induced by soaking seeds in water or in solutions containing exogenous molecules such as salts (Khan et al. 2009), metals (Mirshekari et al. 2012) or hormones (Nakaune et al. 2012), but then halted by drying of the seeds. Primed seeds tend to show better germination and growth even when imposed to stressful conditions. Although the mechanisms on how priming improves these parameters are still unclear, it has been suggested that the strategy activates a series of physiological processes that improve plant growth under stressful conditions (Varier et al. 2010), including the induction of antioxidant systems (Eisvand et al. 2010).

Hormone pretreatment is a commonly used priming strategy to improve seed germination in 
stressful conditions (Atici et al. 2003, Gratão et al. 2005, Jisha et al. 2013, Masood et al. 2012, $\mathrm{Hu}$ et al. 2013). For example, seeds of rye (Secale montanum) pretreated with gibberellic acid $\left(\mathrm{GA}_{3}\right)$ increased germination in water deficit conditions (Ansari et al. 2013). In pepper (Capscum annum L.), Khan et al. (2009) showed that pretreatment with acetylsalicylic acid and salicylic acid resulted in greater uniformity of germination and establishment of seedlings under high salinity. Additionally, ethylene was used to minimize the effect of high temperatures on seed germination of lettuce (Lactuca sativa L.) (Nascimento 2004). In the present study, we aimed to investigate whether hormone priming alters the physiological responses of the economically important pigeon pea (Cajanus cajan L. Mill sp - Fabaceae), when grown under Cd stress.

\section{MATERIALS AND METHODS}

\section{Plant MATERIAL AND PRIMING TREATMENTS}

Pigeon pea (Cajanus Cajan (L.) Mill sp) seeds were soaked for $17 \mathrm{~h}\left(25^{\circ} \mathrm{C}\right.$, dark $)$ in $200 \mathrm{~mL}$ solutions containing 10 or $100 \mu \mathrm{M}$ of the following hormones: Auxin (AUX- indolebutyric acid or IBA), gibberellin $\left(\mathrm{GA}_{3}\right)$, cytokinin (CK, 6-benzilaminopurine or 6-BAP), ethylene (ET, chloroethylphosphonic acid or CEPA), abscisic acid (ABA) and distilled water (hydro-priming). Non-priming seeds (NP) were taken as control. After the priming treatment, seeds were washed with distilled water and dried on filter paper at room temperature (in shade) for $24 \mathrm{~h}$ (Bennett and Waters 1987, Khan 1992).

STRESS INDUCTION

Seeds were then sterilized for three minutes in a solution of 5\% sodium hypochlorite and allowed to germinate in plastic containers containing two layers of filter paper moistened with distilled water. After four days, a solution containing $50 \mu \mathrm{M}$ cadmium chloride $\left(\mathrm{CdCl}_{2}\right)$ was added to the containers. As a mock control, a set of seeds were left in water. The experiment was conducted in a growth chamber at $25^{\circ} \mathrm{C}$ and long-day photoperiod (16h light).

\section{GERMINATION TEST}

We used four replicates of 36 seeds to calculate: (i) the percentage of seeds that germinated $\left[\left(\mathrm{G}_{\mathrm{i}} \%=\right.\right.$ $(n i / N) \times 100)]$; (ii) the final germination percentage $\left[\left(\mathrm{G}_{\mathrm{f}} \%=(n f / \mathrm{N}) \times 100\right)\right]$, where $n i$ and $n f$ were, respectively, the number of seeds germinated every day or at the end of the whole experiment (7 days), and $N$ was the number of seeds included in the test; (iii) the germination speed index $\left[\mathrm{GSI}=\sum(n i / t i)\right]$, where $t i$ was day $i$; (iv) the average germination time $\left[\mathrm{AGT}=\sum(t i . n i) / \sum n\right]$ and; (v) the time to reach $50 \%$ germination $\left\{\mathrm{T}_{50}=t_{i}+\left[(N / 2)-n_{i}\right]\left(t_{j}-\right.\right.$ $\left.\left.t_{i}\right) / n_{j}-n_{i}\right\}$, where $N$ is the final number of seeds that germinated and $n_{i}$ and $n_{j}$ were the cumulative number of seeds germinated by adjacent counts at times $t_{i}$ and $t_{j}$ when $n i<N / 2<n j$ (Coolbear et al. 1984, Farooq et al. 2005). Germination was defined as the visible emergence of the radicle through the seed coat (Maguire 1962, Galmés et al. 2006).

\section{STATISTICAL ANALYSES}

The data was submitted to statistical analysis by using analysis of variance (ANOVA) where means were compared between treatments by LSD (least significant difference) at the 0.05 confidence level using Tukey's test.

\section{RESULTS AND DISCUSSION}

Results of the experiment with AUX, CK, GA 3 , ABA priming and hydro-priming showed that, even under Cd stress, pigeon pea seed germination was improved after $48 \mathrm{~h}$ as compared to NP control (Fig. 1a-1h). Although we found higher values of $\mathrm{G}_{\mathrm{f}} \%$ in the hormone treated seeds when compared to the NP, the fact that these values did not differ from seed treated with hydro-priming indicates that $\mathrm{H}_{2} \mathrm{O}$ itself and not the presence of AUX, $\mathrm{CK}, \mathrm{GA}_{3}$ in the solutions lead to the germination 


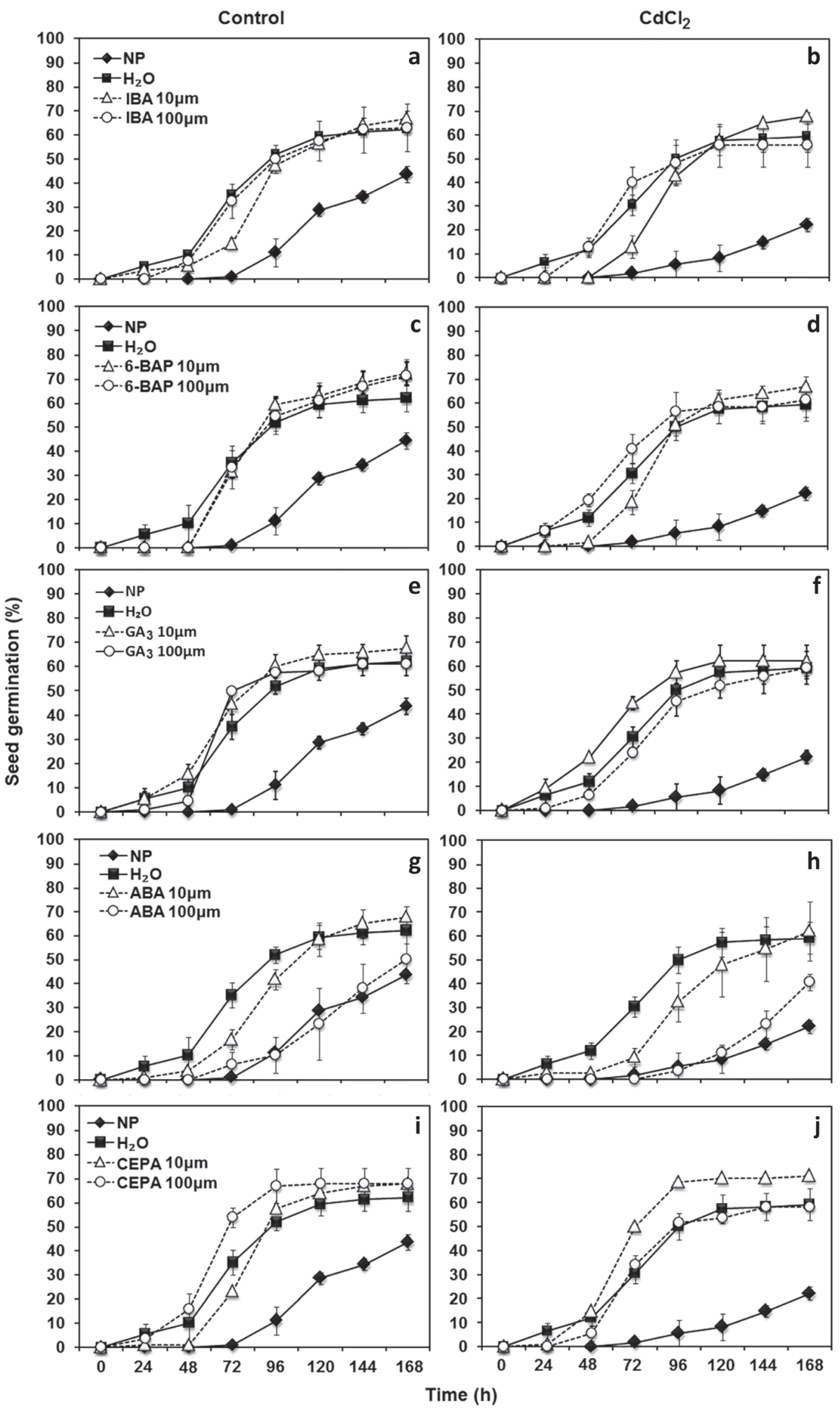

Figure 1 - Seed germination percentage at $24 \mathrm{~h}$ intervals $\left(\mathrm{G}_{\mathrm{f}} \%\right)$ of pigeon pea seeds pretreated with hormones (a-b) auxin (IBA), (c-d) cytokinin (6-BAP), (e-f) gibberellins (GA), (g-h) abscisic acid (ABA) and (i-j) ethylene (CEPA) incubated in control condition or under cadmium stress $\left(\mathrm{CdCl}_{2}\right)$ during $168 \mathrm{~h}$. Error bars represent $\pm \mathrm{SE}$. 
improvement (Table I). Interestingly, we found that until $120 \mathrm{~h}$ after induction of germination, seeds treated with $100 \mu \mathrm{M}$ ABA had similar germination rates of NP (Fig. 1g and 1h). The results obtained with the higher concentration of ABA $(100 \mu \mathrm{M})$ was probably related to the known inhibitory action that ABA carries on the synthesis of enzymes involved in the degradation of endosperm cell wall, an important step for seed germination (Nambara et al. 2010, Linkies and Leubner-Metzger 2012).

TABLE I

Germination speed index (GSI), average germination time (AGT), time to reach $50 \%$ germination $\left(T_{50}\right)$ and final germination percentage $\left(G_{f} \%\right)$ obtained from seeds of pigeon pea pretreated with the hormones auxin (IBA), cytokinin (6-BAP), gibberellins ( $\left(\mathrm{GA}_{3}\right)$, ethylene (CEPA) and abscisic acid (ABA) and distilled water (hydro-priming) while non-priming seeds (NP) were taken as control.

\begin{tabular}{|c|c|c|c|c|c|c|c|c|c|}
\hline \multirow{2}{*}{\multicolumn{2}{|c|}{ Treatment }} & \multicolumn{2}{|c|}{ GSI } & \multicolumn{2}{|c|}{ AGT } & \multicolumn{2}{|c|}{$\mathbf{T}_{50}$} & \multicolumn{2}{|c|}{$\mathrm{G}_{\mathrm{f}} \%$} \\
\hline & & $\mathrm{H}_{2} \mathrm{O}$ & $\mathrm{CdCl}_{2}$ & $\mathrm{H}_{2} \mathrm{O}$ & $\mathrm{CdCl}_{2}$ & $\mathrm{H}_{2} \mathrm{O}$ & $\mathrm{CdCl}_{2}$ & $\mathrm{H}_{2} \mathrm{O}$ & $\mathrm{CdCl}_{2}$ \\
\hline \multirow{4}{*}{$\underset{\Theta}{\mathscr{\theta}}$} & NP & $0.13 \pm 0.01$ & $0.06 \pm 0.01$ & $125.97 \pm 7.43$ & $136.00 \pm 13.68$ & $112.21 \pm 8.66^{\mathrm{a}}$ & $192.05 \pm 6.11^{\mathrm{b}}$ & $43.52 \pm 3.34^{\mathrm{a}}$ & $22.22 \pm 2.78^{b}$ \\
\hline & $\mathrm{H}_{2} \mathrm{O}$ & $0.33 \pm 0.06^{*}$ & $0.33 \pm 0.02^{*}$ & $80.54 \pm 9.42^{*}$ & $79.57 \pm 6.41^{*}$ & $62.68 \pm 13.03^{*}$ & $59.67 \pm 5.17^{*}$ & $62.04 \pm 5.63^{*}$ & $59.26 \pm 6.68^{*}$ \\
\hline & $10 \mu \mathrm{M}$ & $0.29 \pm 0.03^{\mathrm{a}^{*}}$ & $0.24 \pm 0.01^{\mathrm{b}^{* \boldsymbol{\Lambda}}}$ & $98.72 \pm 4.28^{* \boldsymbol{\Lambda}}$ & $104.92 \pm 1.58^{* \boldsymbol{\Lambda}}$ & $80.02 \pm 6.22^{\Lambda}$ & $88.54 \pm 1.57^{* \boldsymbol{\Lambda}}$ & $66.67 \pm 3.21^{*}$ & $67.59 \pm 1.85^{*}$ \\
\hline & $100 \mu \mathrm{M}$ & $0.28 \pm 0.03^{* \boldsymbol{\Lambda}}$ & $0.28 \pm 0.05^{*}$ & $87.48 \pm 2.99^{\mathrm{a}^{*} \boldsymbol{\Delta}}$ & $76.83 \pm 1.49^{\mathrm{b}^{*}}$ & $67.39 \pm 5.49^{*}$ & $59.13 \pm 4.37^{*}$ & $62.96 \pm 9.80^{*}$ & $55.56 \pm 8.93^{*}$ \\
\hline \multirow{2}{*}{$\frac{\hat{c}}{\text { bे }}$} & $10 \mu \mathrm{M}$ & $0.29 \pm 0.01^{\mathrm{a}^{*}}$ & $0.27 \pm 0.02^{\mathrm{b}^{* \boldsymbol{\Lambda}}}$ & $93.72 \pm 4.12^{* \mathbf{\Delta}}$ & $99.66 \pm 1.55^{* \mathbf{\Delta}}$ & $77.49 \pm 2.77^{\boldsymbol{\Lambda}}$ & $79.13 \pm 3.51^{* \mathbf{\Delta}}$ & $72.22 \pm 4.81^{*}$ & $69.44 \pm 3.21^{*}$ \\
\hline & $100 \mu \mathrm{M}$ & $0.29 \pm 0.03^{*}$ & $0.37 \pm 0.02^{*}$ & $95.19 \pm 6.23^{\mathrm{a}^{*} \boldsymbol{\Lambda}}$ & $73.81 \pm 0.33^{b^{* \boldsymbol{\Lambda}}}$ & $79.87 \pm 3.17^{\mathrm{a} \Lambda}$ & $51.74 \pm 3.05^{\mathrm{b}^{*}}$ & $71.30 \pm 6.68^{*}$ & $61.11 \pm 6.99^{*}$ \\
\hline \multirow{2}{*}{$\bigotimes^{\infty}$} & $10 \mu \mathrm{M}$ & $0.38 \pm 0.05^{*}$ & $0.41 \pm 0.05^{*}$ & $77.08 \pm 1.30^{\mathrm{a}^{*}}$ & $68.21 \pm 1.01^{\mathrm{a}^{* \boldsymbol{\Lambda}}}$ & $55.02 \pm 5.76^{*}$ & $47.04 \pm 1.98^{*}$ & $67.59 \pm 5.16^{*}$ & $62.04 \pm 6.48^{*}$ \\
\hline & $100 \mu \mathrm{M}$ & $0.31 \pm 0.02^{\mathrm{a}^{*}}$ & $0.26 \pm 0.03^{\mathrm{b}^{*} \boldsymbol{\Lambda}}$ & $76.73 \pm 1.82^{\mathrm{a}^{*}}$ & $93.76 \pm 2.47^{b^{*} \boldsymbol{\Lambda}}$ & $67.90 \pm 5.25^{*}$ & $70.56 \pm 1.85^{*}$ & $61.11 \pm 0.00^{*}$ & $59.26 \pm 4.63^{*}$ \\
\hline \multirow{2}{*}{ है } & $10 \mu \mathrm{M}$ & $0.27 \pm 0.02^{* \boldsymbol{\Delta}}$ & $0.24 \pm 0.05^{* \boldsymbol{\Delta}}$ & $101.61 \pm 5.53^{* \boldsymbol{\Lambda}}$ & $110.27 \pm 2.59^{* \boldsymbol{\Delta}}$ & $82.74 \pm 6.48^{\mathbf{\Lambda}}$ & $92.25 \pm 4.68^{* \boldsymbol{\Lambda}}$ & $67.59 \pm 4.63^{*}$ & $62.96 \pm 11.82^{*}$ \\
\hline & $100 \mu \mathrm{M}$ & $0.15 \pm 0.04^{\boldsymbol{\Lambda}}$ & $0.10 \pm 0.01 \wedge$ & $134.17 \pm 9.68^{\mathbf{\Lambda}}$ & $146.24 \pm 3.90^{\mathbf{\Lambda}}$ & $114.55 \pm 6.36^{\boldsymbol{\Lambda}}$ & $127.32 \pm 3.95^{* \boldsymbol{\Lambda}}$ & $50.00 \pm 10.02^{\mathrm{a}}$ & $40.74 \pm 3.34^{\mathrm{b}^{*} \boldsymbol{\Lambda}}$ \\
\hline \multirow{2}{*}{$\underset{\mathbf{r}}{\overleftarrow{U}}$} & $10 \mu \mathrm{M}$ & $0.28 \pm 0.02^{\mathrm{a}^{*}}$ & $0.37 \pm 0.01^{\mathrm{b}^{*}}$ & $92.49 \pm 2.96^{\mathrm{a}^{* \boldsymbol{\Lambda}}}$ & $75.38 \pm 1.62^{\mathrm{b}^{*} \boldsymbol{\Lambda}}$ & $75.83 \pm 3.44^{\mathrm{a} \Delta}$ & $57.19 \pm 1.34^{\mathrm{b}^{*}}$ & $67.59 \pm 2.45^{*}$ & $71.30 \pm 2.45^{*}$ \\
\hline & $100 \mu \mathrm{M}$ & $0.39 \pm 0.02^{\mathrm{a}^{*}}$ & $0.27 \pm 0.02^{\mathrm{b}^{*} \boldsymbol{\Lambda}}$ & $69.74 \pm 3.20^{\mathrm{a}^{*} \boldsymbol{\Lambda}}$ & $84.28 \pm 1.79^{\mathrm{b}^{*}}$ & $55.06 \pm 7.23^{*}$ & $67.94 \pm 3.76^{*}$ & $67.59 \pm 6.68^{*}$ & $58.33 \pm 1.60^{*}$ \\
\hline
\end{tabular}

Means marked with asterisk in the columm indicate that hormonal priming or $\mathrm{H}_{2} \mathrm{O}$ are different from NP, and means marked with triangle indicates that hormonal priming is different from $\mathrm{H}_{2} \mathrm{O}$ treatment. Different letters in the row indicate that there is significant difference between $\mathrm{H}_{2} \mathrm{O}$ and $\mathrm{CdCl}_{2}$. These differences are obtained from Dunkan's test at $P<0.05$.

In the case of ET, seeds pretreated with $\mathrm{H}_{2} \mathrm{O}$, 10 or $100 \mu \mathrm{M}$ of the exogenous hormone showed, both in control and $\mathrm{CdCl} 2$ treated seeds, higher rates of $\mathrm{G}_{\mathrm{i}} \%$, compared to NP (Fig. 1i and $1 \mathrm{j}$ ). We found an increase in the $\mathrm{G}_{\mathrm{i}} \%$ from seeds pretreated with $10 \mathrm{mM}$ of ET after 48 to $96 \mathrm{~h}$ in the presence of Cd (Fig. 1j), suggesting that ET pretreatment lead to a decreased sensitivity or tolerance to exogenous applied $\mathrm{Cd}$. However further research is still necessary to prove the role of ET priming on pigeon pea seeds since no differences were observed for GSI, AGT, $\mathrm{T}_{50}$ and $\mathrm{G}_{\mathrm{f}} \%$. Plant responses to ET priming can be rather complex, it has been previously documented that seed priming with ACC (1-aminocyclopropane-1-carboxylic acid), an ethylene precursor, increased the germination rate of lettuce seeds (Nascimento et al. 2004), but not of ryegrass (Tiryaki et al. 2004).

We found that hydro- and not hormone priming is the main factor improving the germination of pigeon pea. This treatment also improves germination efficiency under high $\mathrm{Cd}$ concentrations and can be 
used as an efficient alternative to improve seed germination in $\mathrm{Cd}$ contamined areas. Hormonal effects were observed for high ABA concentrations, where we demonstrate the inhibitory action of this hormone during pre-germination period. We also observed a trend of tolerance to the effects of $\mathrm{Cd}$ in the presence of exogenous ET, but further studies are still necessary to prove the role of this hormone during heavy-metal tolerance.

\section{ACKNOWLEDGMENTS}

We would like to thank the "Coordenação de Aperfeiçoamento de Pessoal de Nível Superior (CAPES) and "Pró-Reitoria de Pesquisa" (ProPeUnesp) for their financial support.

\section{RESUMO}

No presente trabalho nós investigamos como o prétratamento com auxina, citocinina, giberelina, ácido abscísico e etileno alteram as respostas fisiológicas de sementes de feijão guandu germinadas em água e sob estresse causado por excesso de cádmio. As sementes tratadas com água ou não-tratadas foram utilizadas como controle. Quando comparadas às sementes não tratadas, percebemos que os pré-tratamentos hormonais resultaram em um aumento na germinação do feijão guandu na condição de estresse. Entretanto, esses tratamentos não diferiram daqueles apenas com água. Nós também observamos uma tendência de tolerância aos efeitos do cádmio na presença de etileno, sugerindo que o uso desse hormônio possa ser um método eficiente para superar o efeito do estresse por cádmio durante a germinação de sementes.

Palavras-chave: Cajanus Cajan, metal pesado, hormônio, pré-tratamento de sementes, estresse abiótico.

\section{REFERENCES}

ANSARI O, AZADI MS, SHARIF-ZADEH F AND YounEsi E. 2013. Effect of hormone priming on germination characteristics and enzyme activity of mountain rye (Secale montanum) seeds under drought stress conditions. J Stress Physiol Biochem 9: 61-71.
ARASIMOWICZ-JELONEK M, FLORYSZAK-WIECZOREK MJ AND GWÓźDŹ EA. 2011. The message of nitric oxide in cadmium challenged plants. Plant Sci 181: 612-620.

Atici O, AgAR G AND BatTAL P. 2003. Interaction between endogenous plant hormones and alphamylase in germinating chickpeas seeds under cadmium exposure. Fresenius Environ Bull 12: 781-785.

BENNETT MA AND WATERS JR L. 1987. Seed hydration treatments to improve sweet maize germination and stand establishment. J Amer Soc Hort Sci 112: 45-49.

COOLBEAR P, Francis A AND GRIERSON D. 1984. The effect of low temperature pre-sowing treatment on the germination performance and membrane integrity of artificially aged tomato seeds. J Exp Bot 35: 1609-1617.

CUI W, GAO C, FANG P, LIN G AND SHEN W. 2013. Alleviation of cadmium toxicity in Medicago sativa by hydrogen-rich water. J Hazard Mater 260: 715-724.

EISVAND HR, TAVAKKOL-AFSHARI R, SHARIFZADEH F, MAdDAH AREFI H AND HeSAmZadeH HeJazi SM. 2010. Effects of hormonal priming and drought stress on activity and isozyme profiles of antioxidant enzymes in deteriorated seed of tall wheatgrass (Agropyron elongatum Host). Seed Sci Technol 38: 280-297.

Faroog M, Basra SMA, Ahmad N AND Hafeez K. 2005. Thermal hardening: A new seed vigor enhancement tool in rice. J Integr Plant Biol 47: 187-193.

Galmés J, Medrano H AND FleXAs J. 2006. Germination capacity and temperature dependence in Mediterranean species of the Balearic Islands. Invest Agr Sist Rec For 15: 88-95.

Gill SS AND TUteJA N. 2011. Cadmium stress tolerance in crop plants: probing the role of sulfur. Plant Signal Behav 6: 215-222.

Gratão PL, Polle A, LeA PJ AND AZEVEdo RA. 2005. Making the life of heavy metal-stressed plants a little easier. Funct Plant Biol 32: 481-494.

HU YF, ZHOU G, NA XF, YANG L, NAN WB, ZHANG YO, LI JL AND BI YR. 2013. Cadmium interferes with maintenance of auxin homeostasis in Arabidopsis seedlings. J Plant Physiol 170: 965-975.

JARUP L AND AKESSON A. 2009. Current status of cadmium as an environmental health problem. Toxicol Appl Pharmacol 238: 201-208.

Jisha KC, ViJaYAKumari K AND PUthur JT. 2013. Seed priming for abiotic stress tolerance: an overview. Acta Physiol Plant 35: 1381-1396.

KHAN AA. 1992. Preplant physiological seed conditioning. Hortic Rev 13: 131-181.

Khan HA, Ayub CM, Pervez MA, Bilal RM, Shahid MA AND ZIAF K. 2009. Effect of seed priming with $\mathrm{NaCl}$ on salinity tolerance of hot pepper (Capsicum annuum L.) at seedling stage. Soil Environ 28: 81-87.

Khan HA, Pervez MA, Ayub CM, Ziaf K, Bilal RM, Shahid MA AND AKHTAR N. 2009. Hormonal priming alleviates salt stress in hot pepper (Capsicum annuum L.). Soil Env 28: $130-135$. 
LINKIES A AND LEUBNER-MEtZGER G. 2012. Beyond gibberellins and abscisic acid: how ethylene and jasmonates control seed germination. Plant Cell Reports 31: $253-270$

MAGUIRE JD. 1962. Speed of Germination - aid in selection and evaluation for seedling emergence and vigor1. Crop Sci 2: 176-177.

MASOOD A, IQBAL N AND KHAN NA. 2012. Role of ethylene in alleviation of cadmium-induced capacity inhibition by sulphur in mustard. Plant Cell Environ 35: 524-533.

MirsheKARI B, BASER S, ALlAHYARI S AND HAMENDANLU N. 2012. 'On-farm' seed priming with $\mathrm{Zn}$ plus $\mathrm{Mn}$ is an effective way to improve germination and yield of marigold. Afr J Microbiol Res 6: 5796-5800.

NAKaUne M, HANAda A, Yin Y, MatsukURA C, YAMAGUCHI S AND EZURA H. 2012. Molecular and physiological dissection of enhanced seed germination using shortterm low-concentration salt seed priming in tomato. Plant Physiol Biochem 52: 28-37.
NAmbara E, OKAMoto $M$, TATEmatsu $K$, Yano $R$ MITSUNORI S AND KAMIYA Y. 2010. Abscisic acid and the control of seed dormancy and germination. Seed Sci Res 20: 55-67.

NASCIMENTO WM. 2004. Condicionamento osmótico de sementes de hortaliças: potencialidades e implicações. Hortic Bras 16: 106-109.

NAscimento WM, CANTLIFFe DJ AND Huber DJ. 2004. Ethylene evolution and endo-â-mannanase activity during lettuce seed germination at high temperature. Sci Agric 61: 156-163.

TIRYAKI I, KORKMAZ A, OZBAY N AND NAS MN. 2004. Priming in the presence in the plant growth regulators hastens germination and seedling emergence of dormant annual ryegrass (Lilium multiflorum Lam.) seeds. Asian J Plant Sci 3: 655-659.

VARIER A, VARI AK AND DADLANI M. 2010. The subcellular basis of seed priming. Curr Sci India 99: 451-456. 